Abeer Mohamed Nageeb Mohamed et al., Effect of fibers type on flexural behavior of high performance concrete beams under repeated load, pp. $2103-2125$

\title{
EFFECT OF FIBERS TYPE ON FLEXURAL BEHAVIOR OF HIGH PERFORMANCE CONCRETE BEAMS UNDER REPEATED LOAD
}

\author{
Aly Abdel Zaher Elsayed ${ }^{1}$, Mohamed M. Rashwan ${ }^{2}$, Hesham Mohamed Diab ${ }^{3}$, \\ Ali Mohamed Abdallah ${ }^{4}$ and Abeer Mohamed Nageeb Mohamed ${ }^{5, *}$ \\ 1, 2, 3 Staff in Civil Engineering Department, Faculty of Engineering, Assiut University, Assiut, Egypt. \\ ${ }^{4}$ Civil Engineering Department, Faculty of Engineering, Kafrelsheikh University. \\ ${ }^{5}$ Civil Engineer, Assiut University, 2008.
}

Received 29 September 2013; November 21 October 2013

\begin{abstract}
The need of high performance concrete HPC is increasing in the recent years. This material becomes necessary, but it is brittle. So, fibers are used to enhance mechanical properties of HPC. The enhanced properties include tensile strength, compressive strength, elastic modulus, crack resistance, crack control, durability, fatigue life, resistance to impact and abrasion, shrinkage, expansion, thermal characteristic, and fire resistance of concrete. The main objective of this research is to study the effect of using Harex, polypropylene and glass fibers on flexural behavior of High performance concrete beams under static and repeated loads.
\end{abstract}

Keywords: high performance concrete, beams, harex fiber, polypropylene fiber, glass fiber, static loading, repeated loading

\section{Introduction}

Concrete being a brittle material has low tensile strength and low strain capacity, as a result, the mechanical behaviour of the concrete is critically influenced by crack propagation. Concrete in service may exhibit failure through cracks which are developed due to brittleness [ K. komlos, B. Babal, and T. Nurnbergerova. 1995]. To improve properties of concrete like low tensile and low strain capacity, fiber reinforced concrete (FRC) has been developed which is defined as concrete containing dispersed randomly oriented fibers [Johnston C.D. 1974].

Fibers had been used to reinforce cementitious material since ancient times, sun-backed bricks were reinforced by using straw as fiber and masonry mortar and plaster were reinforced using horsehair. Experimental investigation involving the use of discontinuous fibers to improve the properties of concrete was started in 1910 [ Naaman A. E. 1985]. During the early 1960, the first major investigation was made to evaluate the potential of steel fibers as reinforcement of the concrete [ Romualdi, J. P. and Batson G. B. 1963].

The properties of concrete matrix and of the fibers greatly influence the character and performance of FRC. The properties of fibers which are of interest include fiber stiffness, bond between fiber and concrete matrix, fiber concentration, fiber geometry, fiber orientation, fiber distribution and fiber aspect ratio [John E. Bolander 2004].

The mixture-stiffening or workability effect is a major factor limiting the type, aspect ratio and amount of fibers that can be uniformly distributed throughout a particular cementitious matrix, which in turn determine the degree of improvement in the mechanical properties of composites in hardened state. Ideally the amount of fibers and aspect ratio

\footnotetext{
* Corresponding author.

E-mail: address:abeer.nageeb@yahoo.com
} 
Abeer Mohamed Nageeb Mohamed et al., Effect of fibers type on flexural behavior of high performance concrete beams under repeated load, pp. $2103-2125$

should be as large as possible to maximise the improvements in the mechanical properties. On the other hand, both should be as small as possible (but compatible with aggregate size) to minimise the mixture-stiffenin effect of fibers and associated difficulties in fabricating components from FRC [Johnston C. D. 1996].

FRC has been used for numerous applications throughout the construction industry, such as in highways and airport runways, in shotcrete tunnel wall linings, as minimum shear and transverse reinforcement in precast bridge sections and decks, and in slabs-ongrade (Wang et al., 1987; Meda et al., 2005; Minelli, 2005). Steel fibres have also seen limited use in framed slabs and in other flexure-critical structural members (Meda et al., 2005). However, FRC has not been substantially utilized in more critical structural elements (Richardson and Landless, 2009). This is likely attributable to the limited development of rational design codes and standards needed to build the confidence of practitioners in the benefits and application of the material (Lee et al., 2013; Noghabai, 2000).

The main objective of this research is to predict the behavior of high performance R.C concrete beams under static and repeated loads taking the effect of adding different type of fibers on the flexural behavior of high performance R.C concrete beams.

\section{Experimental Work}

Eight beams were tested with main steel diameter $2 \# 18 \mathrm{~mm}$ having rectangular cross section equal to $12 \times 30 \mathrm{~cm}$ as shown in fig(1). The considered span for all tested beams were $240 \mathrm{~cm}$ as showen in fig (1). The study takes in to consideration the following parameters:

1. Type of loading (static and repeated).

2. Types of fibers (Harex, polypropylene and glass).

\section{Group of beam without fibers under static load}

\begin{tabular}{|c|c|c|}
\hline group & fibers\% & fiber type \\
\hline B-S0 & - & - \\
\hline
\end{tabular}

2. Group of beams with fibers under static load

\begin{tabular}{|c|c|c|}
\hline group & fibers $\%$ & fiber type \\
\hline B-Sh & 3 & harex fiber \\
\hline B-S $S_{\mathrm{p}}$ & 3 & polypropylene fiber \\
\hline B-Sg & 3 & glass fiber \\
\hline
\end{tabular}

3. Group of beam without fibers under repeated load

\begin{tabular}{|c|c|c|}
\hline group & fibers\% & fiber type \\
\hline B-R0 & - & - \\
\hline
\end{tabular}

Journal of Engineering Sciences, Assiut University, Faculty of Engineering, Vol. 41, No. 6, November, 2013, E-mail address: jes@aun.edu.eg 
Abeer Mohamed Nageeb Mohamed et al., Effect of fibers type on flexural behavior of high performance concrete beams under repeated load, pp. $2103-2125$

\section{Group of beams with fibers under repeated load}

\begin{tabular}{|c|c|c|}
\hline group & fibers $\%$ & fiber type \\
\hline B-Rh & 3 & harex fiber \\
\hline B- $\mathrm{R}_{\mathrm{p}}$ & 3 & polypropylene fiber \\
\hline $\mathrm{B}-\mathrm{Rg}$ & 3 & glass fiber \\
\hline
\end{tabular}

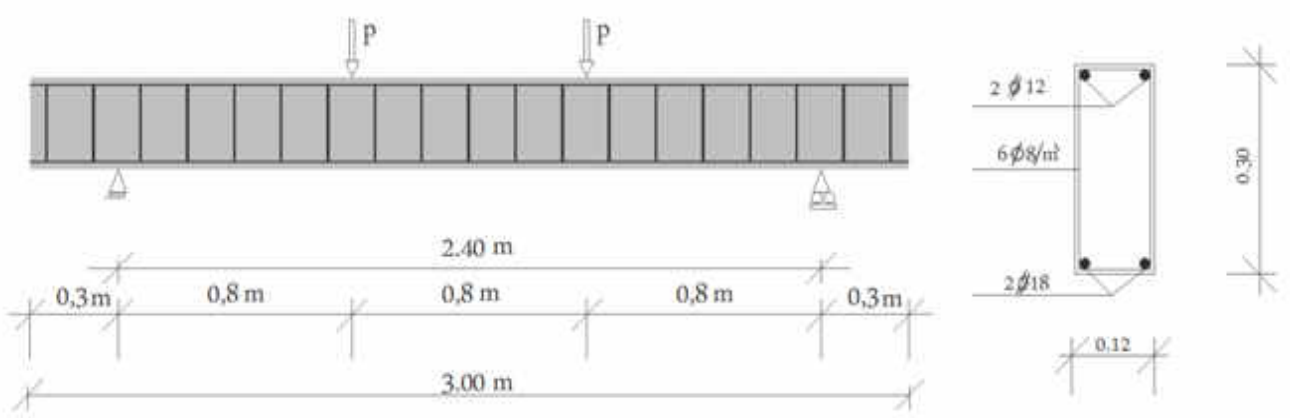

Fig. 1. Beam cross section and reinforcement

\subsection{Materials}

\subsubsection{High performance concrete (H.P.C)}

Concrete mix design was made to produce high performance concrete (H.P.C) with grade $600 \mathrm{~kg} / \mathrm{cm}^{2}$ and its components are given in table (1).

\section{Table1.}

Concrete mix proportion.

\begin{tabular}{|c|c|c|c|c|c|c|c||}
\hline concrete & $\begin{array}{c}\text { Cement } \\
\mathrm{kg} / \mathrm{m}^{3}\end{array}$ & $\begin{array}{c}\text { Silica- } \\
\text { fum } \\
\mathrm{kg} / \mathrm{m}^{3}\end{array}$ & $\begin{array}{c}\text { Water } \\
\text { liter } / \mathrm{m}^{3}\end{array}$ & $\begin{array}{c}\text { Superpl. } \\
\text { liter } / \mathrm{m}^{3}\end{array}$ & $\begin{array}{c}\text { Fine } \\
\text { aggregate } \\
\mathrm{kg} / \mathrm{m}^{3}\end{array}$ & $\begin{array}{c}\text { coarse } \\
\text { aggregate } \\
\mathrm{kg} / \mathrm{m}^{3}\end{array}$ & $\mathrm{Vf} / \mathrm{m}^{3}$ \\
\hline $\mathrm{C}$ & 500 & 110 & 160 & 17.5 & 531 & 1000 & $3 \%$ \\
\hline
\end{tabular}

\subsubsection{Fiber types and its properties}

The study concerned with metallic fibers (harex fiber) and non-metallic fibers (polypropylene and glass). The shape of fibers as shown in Fig. (2), typical properties of various types of the metallic and non-metallic fibers are given in Table (2). 
Abeer Mohamed Nageeb Mohamed et al., Effect of fibers type on flexural behavior of high performance concrete beams under repeated load, pp. $2103-2125$

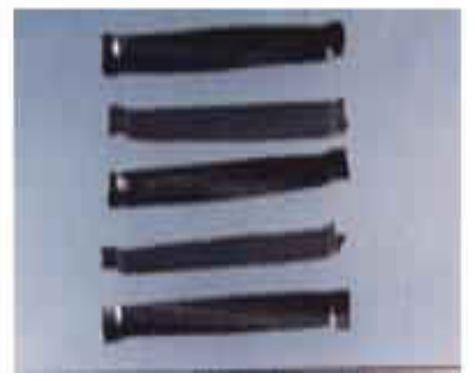

1. Harex steel fiber

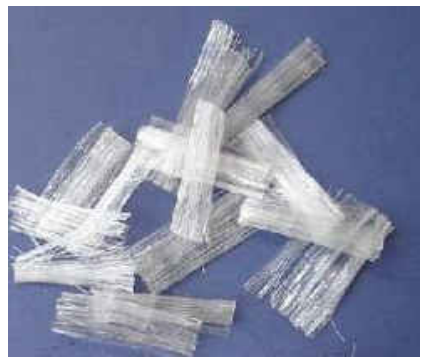

2. Polypropylene

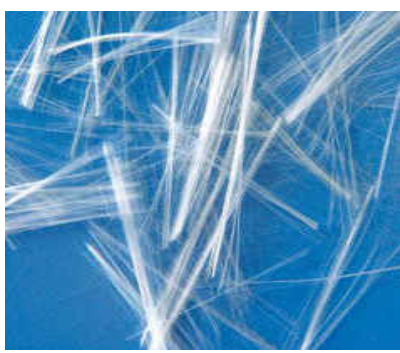

3. Glass fiber

Fig. 2. Fibers type used in beams.

Table 2.

Typical properties of fibers.

\begin{tabular}{|c|c|c|c|c|c|c||}
\hline Type of fiber & $\begin{array}{c}\text { Diameter } \\
(\boldsymbol{\mu} \mathbf{m})\end{array}$ & $\begin{array}{c}\text { Length } \\
(\mathbf{m m})\end{array}$ & $\begin{array}{c}\text { Density } \\
\mathbf{( g m / \mathbf { c m } 3 )}\end{array}$ & $\begin{array}{c}\text { Tensile } \\
\text { Strength } \\
\mathbf{k g} / \mathbf{c m} 2\end{array}$ & $\begin{array}{c}\text { Young's } \\
\mathbf{m o d u l u s} \\
\mathbf{k g} / \mathbf{c m} 2\end{array}$ & $\begin{array}{c}\text { Elongation } \\
(\mathbf{\%})\end{array}$ \\
\hline $\begin{array}{c}\text { Harex steel fiber } \\
\text { Polypropylene } \\
\text { fiber }\end{array}$ & 1000 & 32 & 7.8 & $2 * 10^{4}$ & $2 * 10^{6}$ & 3 \\
\hline $\begin{array}{c}\text { Glass fiber } \\
\text { (Cem-Fil) }\end{array}$ & $2-20$ & 18 & 0.91 & $0.5 * 10^{4}$ & $0.5 * 10^{5}$ & $8-10$ \\
\hline
\end{tabular}

\subsection{Test procedure}

\subsubsection{Static loading}

Four beams were tested at ages of 28 days under static loading; each of the tested beams was loaded by a minimum load with increment of 0.5 tons; This minimum load was kept constant between two successive increments for about five minutes. During this period, readings of the electrical strain gauges for concrete and steel strain, dial gauges for deflection, and the cracks propagation were recorded at the beginning and at the end of each increment of loading.

\subsubsection{Repeated loading}

The available testing machine (EMS 60 tons $\mathrm{P}_{\mathrm{u}}$ ) was used in repeated load. The testing machine gives a frequency changeable between 300 and 750 load cycle per minute. The stroke of the working piston is adjustable between zero and six mms.

During the fatigue tests the frequency was chosen to be 500 cycle per minute and the chosen stroke of the working piston was $0.2 \mathrm{~mm}$. The selected testing machine is provided with heavy steel tare through which the applied load was transmitted to the tested beam. The own weight of the testing machine tare is 1.4 tons. This weight was released in the rest

Journal of Engineering Sciences, Assiut University, Faculty of Engineering, Vol. 41, No. 6, November, 2013, E-mail address: jes@aun.edu.eg 
Abeer Mohamed Nageeb Mohamed et al., Effect of fibers type on flexural behavior of high performance concrete beams under repeated load, pp. $2103-2125$

on time of tested beams.

The remaining four repeated loading beams were tasted under $60 \%$ of the ultimate static loading tests result. Beams loaded until 1 million cycles loading after that loaded with static load up to failure. Repeated test was summarized on Fig.(3) where the tested beam was firstly subjected to a static cycle, part 1-2. After that strokes were began part 2-3 after 0.5 million cycle the load released gradually to zero load part 3-4. The statically loading again from zero to the level of load part 4-5, After that strokes were began part 5-6 and after another 0.5 million cycle. After complete 1 million cycle the loading case is to be static and increased to the end of beam life.

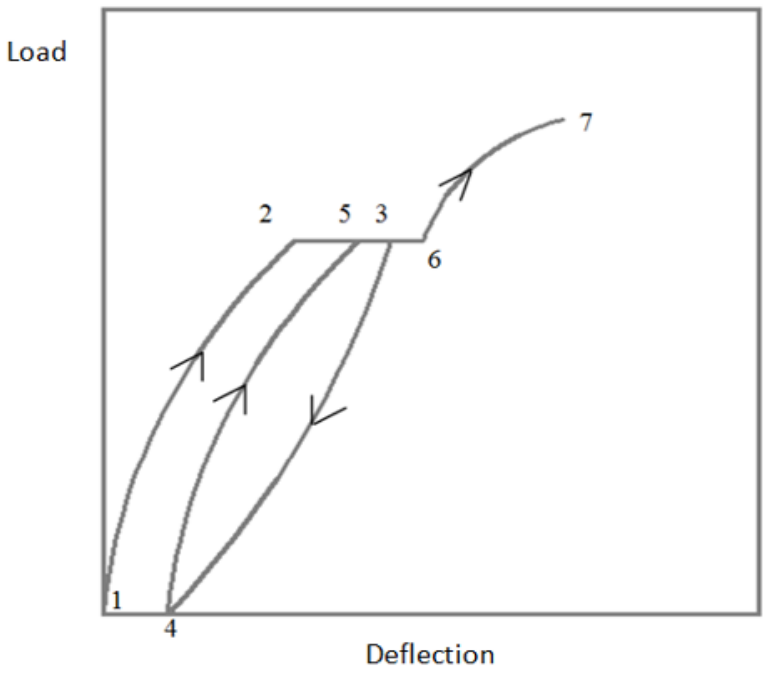

Fig 3. The repeated loading was summarized in this chart.

\subsection{Measured strains of concrete and steel}

Strains of concrete and steel were measured by means of electrical strain gauges at the shown positions in Fig (4). The gauge length was $52 \mathrm{~mm}$, and the $800 \mathrm{~mm}$ resistance was $600 \mathrm{ohms}$ and gauge factor $(2 \pm 0.75 \%)$. Strain gauges were connected to strain indicator with its box résistance. The deflection was measured by dial gauge with accuracy of $0.01 \mathrm{~mm}$ fixed at the position of maximum deflection for each beam as shown in fig (4). 
Abeer Mohamed Nageeb Mohamed et al., Effect of fibers type on flexural behavior of high performance concrete beams under repeated load, pp. $2103-2125$

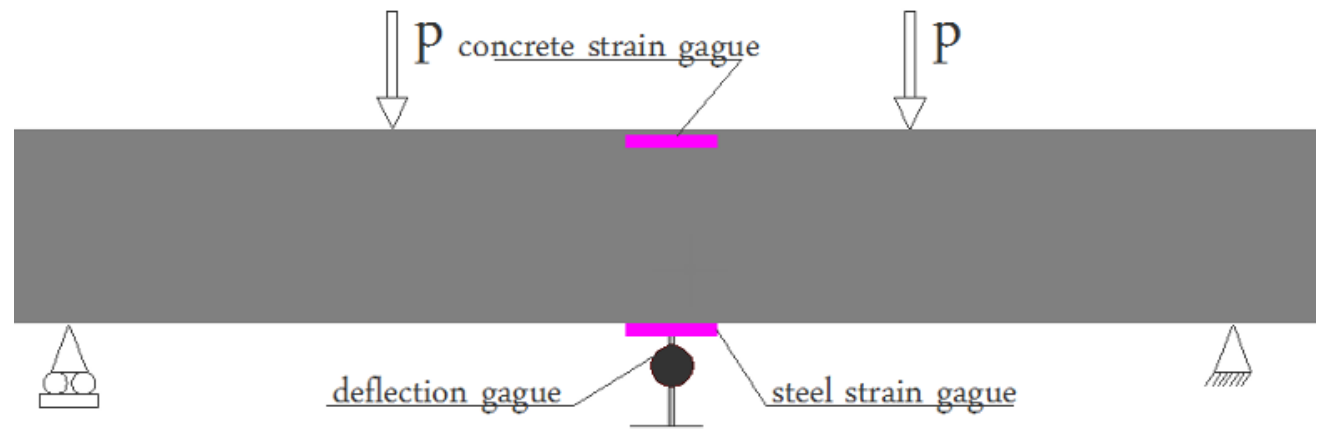

Fig. 4. Method of measuring deformation of beams

\section{Test Result}

\subsection{Crack pattern and mode of failure}

The crack pattern and mode of failure are explained for the tested reinforced high performance concrete (H.P.C) beams. Eight rectangular (H.P.C) reinforced concrete beams tested under static and repeated loading. The cracking and ultimate loads were summarized at table (3) and mode of failure was as follow:

\section{Group of Beams Without Fiber}

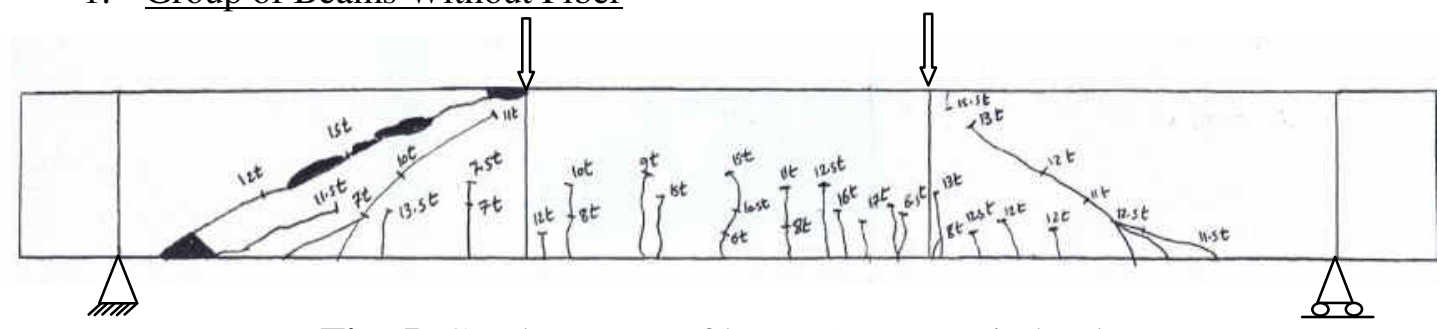

Fig. 5. Crack pattern of beam $\left(\mathrm{Bs}_{0}\right)$ [static load]

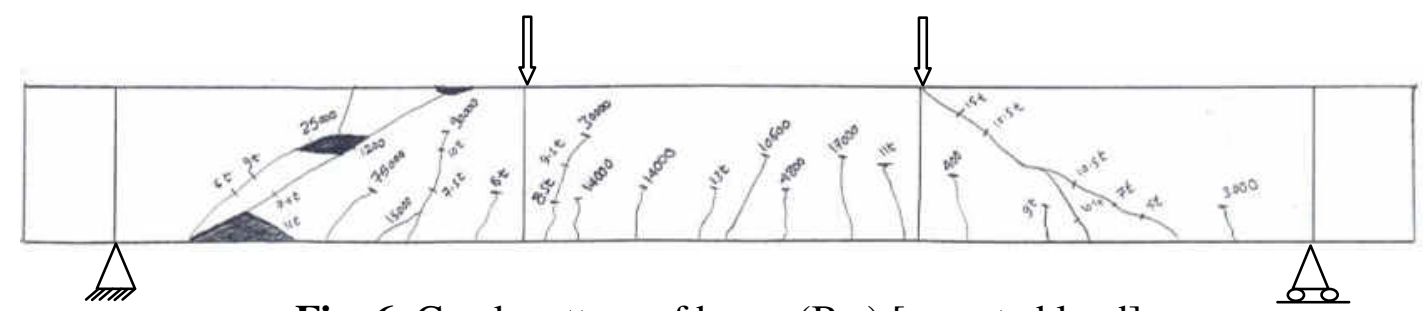

Fig. 6. Crack pattern of beam $\left(\mathrm{Br}_{0}\right)$ [repeated load]

Journal of Engineering Sciences, Assiut University, Faculty of Engineering, Vol. 41, No. 6, November, 2013, E-mail address: jes@aun.edu.eg 
Abeer Mohamed Nageeb Mohamed et al., Effect of fibers type on flexural behavior of high performance concrete beams under repeated load, pp. 2103 - 2125

\section{Group of Beams with Harex Fibers}

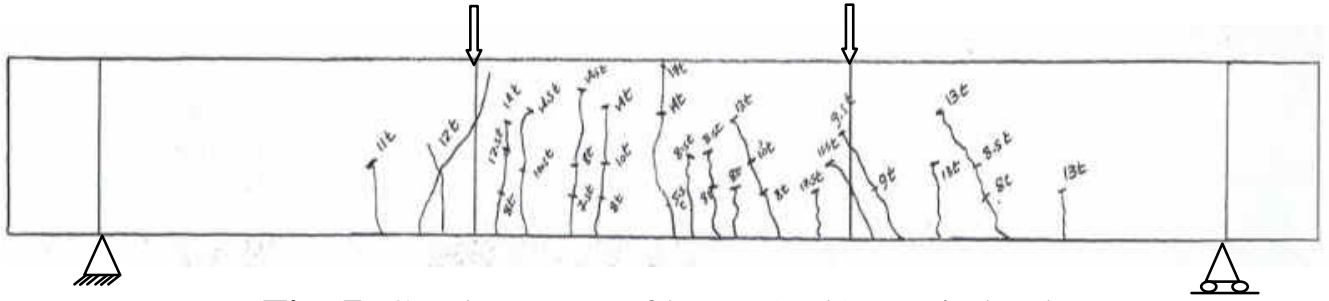

Fig. 7. Crack pattern of beam (Bsh) [static load]

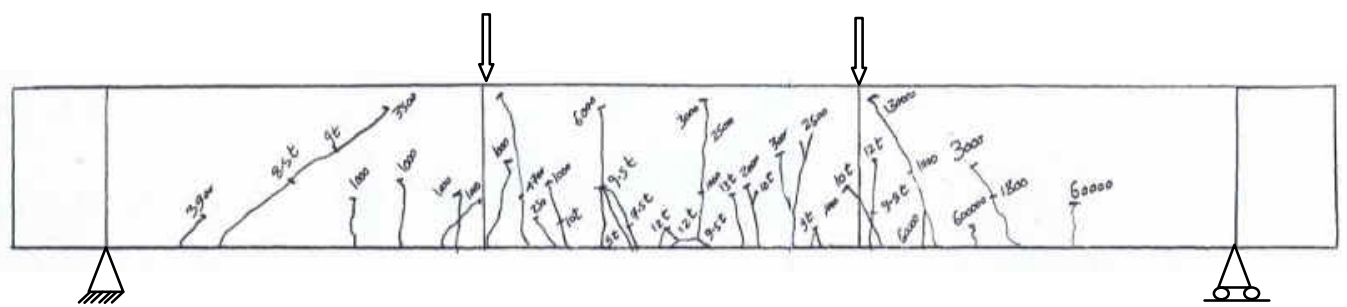

Fig. 8. Crack pattern of beam (Brh [repeated load])

3. Group of Beams with Polypropylene Fibers

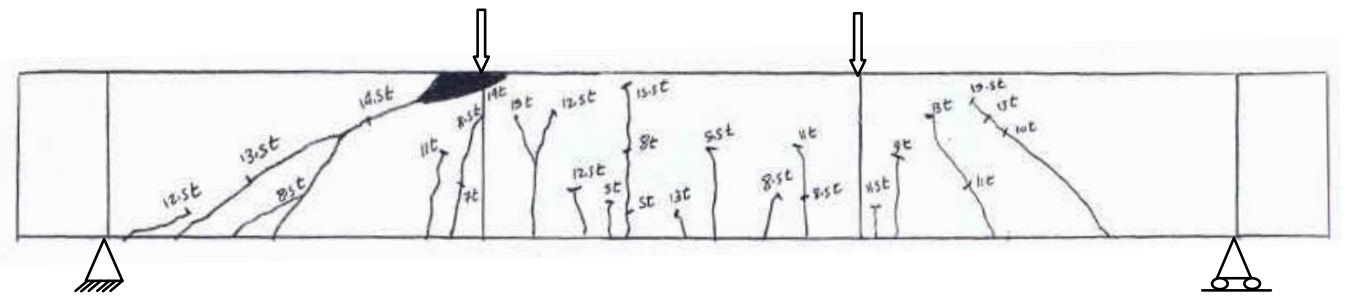

Fig. 9. Crack pattern of beam (Bsp [static load])

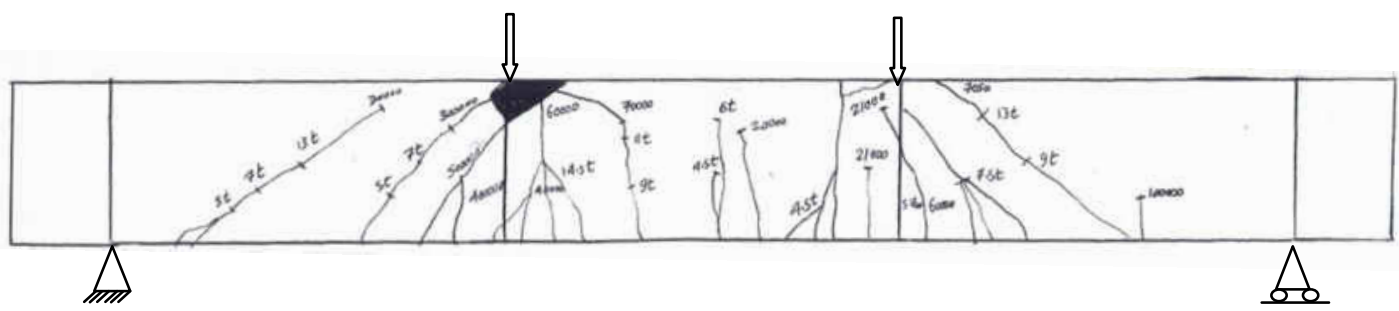

Fig. 10. Crack pattern of beam (Brp) [repeated load]

Journal of Engineering Sciences, Assiut University, Faculty of Engineering, Vol. 41, No. 6, November, 2013,E-mail address: jes@aun.edu.eg 
Abeer Mohamed Nageeb Mohamed et al., Effect of fibers type on flexural behavior of high performance concrete beams under repeated load, pp. $2103-2125$

4. Group of Beams with Glass Fibers

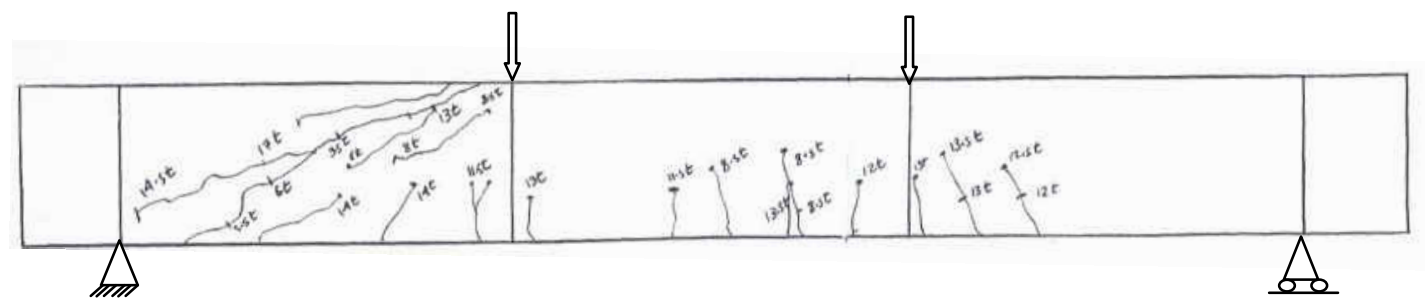

Fig. 11. Crack pattern of beam (Bsg) [static load]

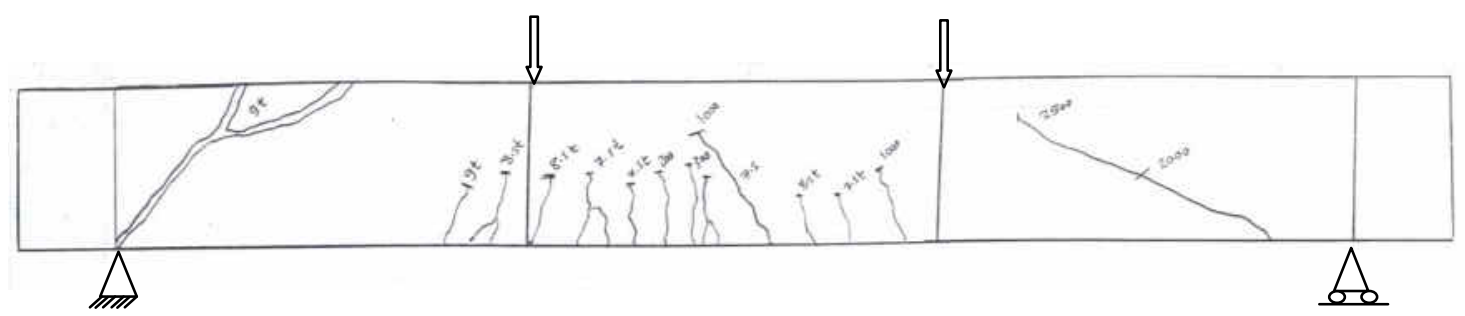

Fig. 12. Crack pattern of beam (Brg) [repeated load]

Table 3.

Cracking and ultimate loads for tested beams under static and repeated loads.

\begin{tabular}{|c|c|c|c|c|c|c|c|}
\hline Group & series & $\begin{array}{c}\text { Type of } \\
\text { fibers }\end{array}$ & $\mathbf{F}_{\mathbf{C}}$ & $\begin{array}{c}\mathbf{P}_{\mathbf{c r}} \\
\text { (ton) }\end{array}$ & $\begin{array}{c}\mathbf{Q}_{\mathbf{c r}} \\
\text { (ton) }\end{array}$ & $\begin{array}{c}\mathbf{P}_{\mathbf{u}} \\
\text { (ton) }\end{array}$ & Mode of failure \\
\hline \multirow{3}{*}{ static } & $\mathrm{Bs} 0$ & $\begin{array}{c}\text { Without } \\
\text { fibers }\end{array}$ & 534 & 4 & 5 & 15.2 & shear failure \\
\cline { 2 - 8 } & $\mathrm{Bsh}$ & $\begin{array}{c}\text { Harex } \\
\text { fibers }\end{array}$ & 721 & 5.1 & 8.5 & 17.5 & flexural failure \\
\cline { 2 - 8 } & $\mathrm{Bsp}$ & $\begin{array}{c}\text { Poly. } \\
\text { fibers }\end{array}$ & 618 & 4.6 & 7 & 16.4 & shear flexural failure \\
\cline { 2 - 8 } & $\mathrm{Bsg}$ & $\begin{array}{c}\text { Glass } \\
\text { fibers }\end{array}$ & 412 & 4.3 & 5 & 14.5 & shear failure \\
\cline { 2 - 8 } repeated & $\mathrm{Br} 0$ & $\begin{array}{c}\text { Without } \\
\text { fibers }\end{array}$ & 534 & 4 & 5 & 15 & shear failure \\
\cline { 2 - 8 } & $\mathrm{Brh}$ & $\begin{array}{c}\text { Harex } \\
\text { fibers }\end{array}$ & 721 & 5.1 & 8.5 & 17.7 & flexural failure \\
\cline { 2 - 8 } & $\mathrm{Brp}$ & 618 & 4.6 & 7 & 16.5 & shear flexural failure \\
\cline { 2 - 8 } & $\mathrm{Brg}$ & $\begin{array}{c}\text { Glass } \\
\text { fibers }\end{array}$ & 412 & 4.3 & 5 & $\begin{array}{c}8.7 \text { at } 0.25 \\
\text { million } \\
\text { cycle }\end{array}$ & shear failure \\
\hline
\end{tabular}

Journal of Engineering Sciences, Assiut University, Faculty of Engineering, Vol. 41, No. 6, November, 2013,E-mail address: jes@aun.edu.eg 
2111

Abeer Mohamed Nageeb Mohamed et al., Effect of fibers type on flexural behavior of high performance concrete beams under repeated load, pp. $2103-2125$

\subsection{Deflection characteristics}

The measured values of maximum deflection are plotted versus the applied load from starting the loading up to failure as shown in Fig. (13),(14). All plotted values indicated that, the deflection increases as the applied load increases.

\subsubsection{Beams tested under static loads}

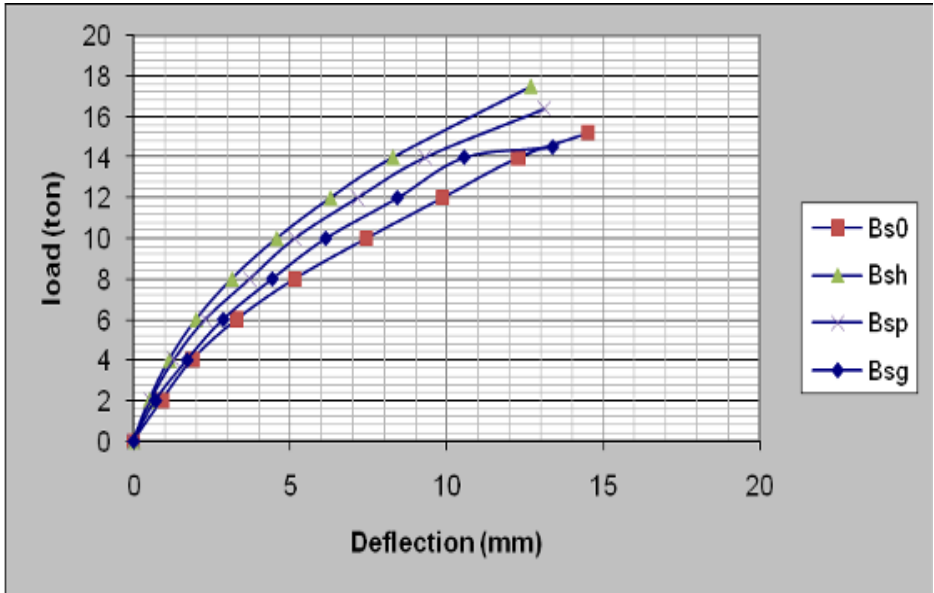

Fig. 13. Load - Mid Span Deflection relationship for beams tested under static loads.

\subsubsection{Beams tested under repeated loads}

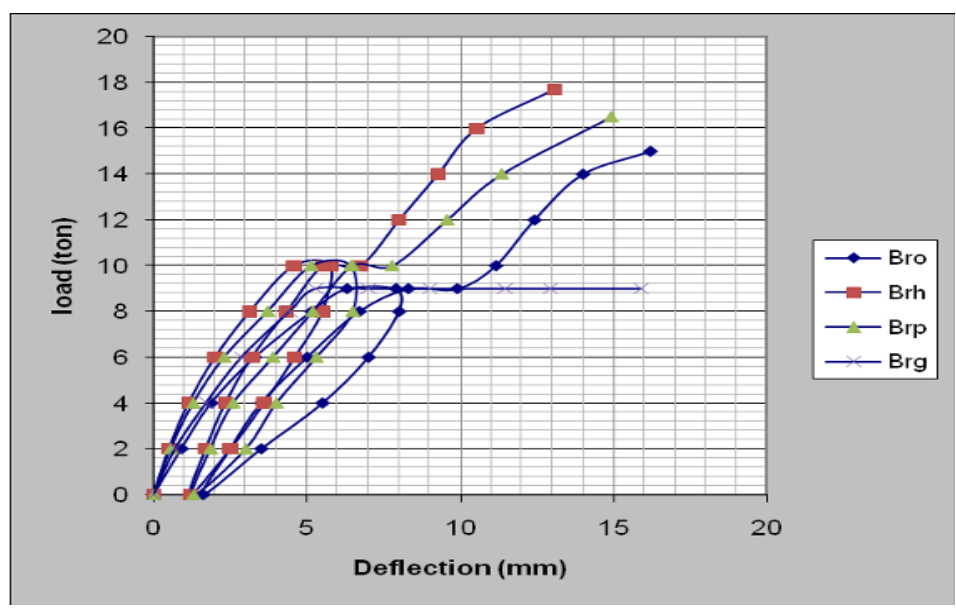

Fig. 14. Load - Mid Span Deflection relationship for beams tested under repeated loads.

\subsection{Concrete Strain Distribution.}

Figure (15),(16) shows the behavior of the concrete strain in compression for all beams. The results indicated that all specimens presented almost have the same trend where as the load increased, the strain also increased.

Journal of Engineering Sciences, Assiut University, Faculty of Engineering, Vol. 41, No. 6, November, 2013,E-mail address: jes@aun.edu.eg 
Abeer Mohamed Nageeb Mohamed et al., Effect of fibers type on flexural behavior of high performance concrete beams under repeated load, pp. $2103-2125$

\subsubsection{Beams tested under static loads}

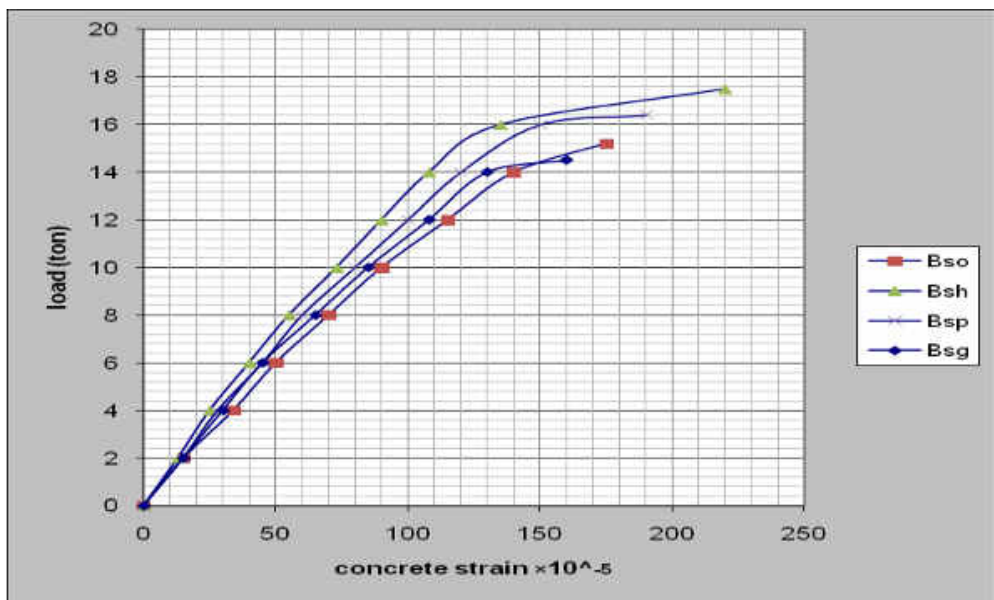

Fig. 15. Concrete Strain Distribution for beams tested under static loads.

\subsubsection{Beams tested under repeated loads}

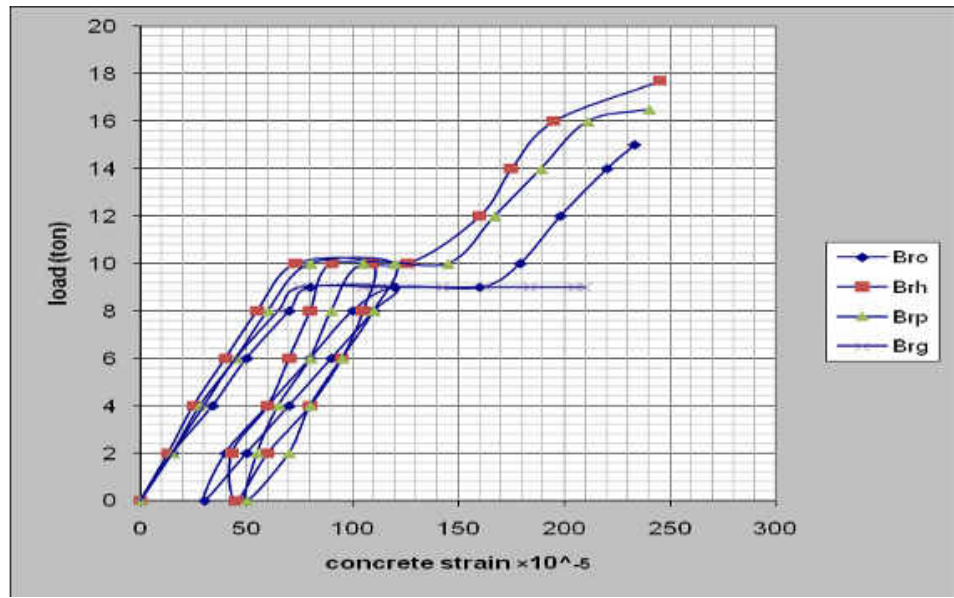

Fig. 16. Concrete Strain Distribution for beams tested under repeated loads.

\subsection{Steel Strain Distribution}

Figure (17),(18) shows the behavior of the steel strain in compression for all beams. The results indicated that all specimens presented almost have the same trend where as the load increased, the strain also increased.

Journal of Engineering Sciences, Assiut University, Faculty of Engineering, Vol. 41, No. 6, November, 2013, E-mail address: jes@aun.edu.eg 
2113

Abeer Mohamed Nageeb Mohamed et al., Effect of fibers type on flexural behavior of high performance concrete beams under repeated load, pp. $2103-2125$

\subsubsection{Beams tested under static loads}

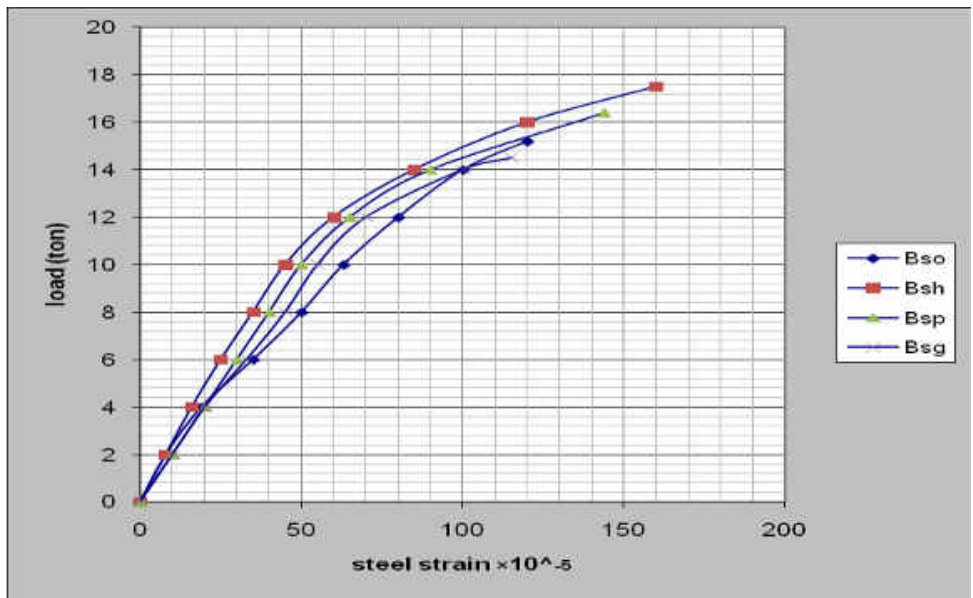

Fig. 17. Steel Strain Distribution for beams tested under static loads

\subsubsection{Beams tested under repeated loads}

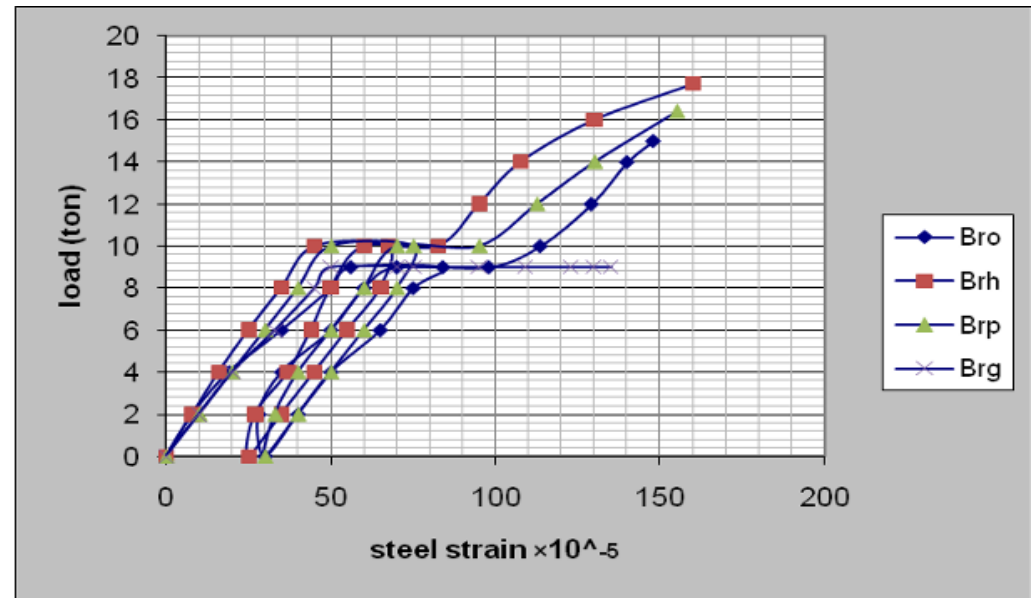

Fig. 18. Steel Strain Distribution for beams tested under repeated loads.

\section{Discussion of Test Result}

This item describes and interprets the analysis of the obtained test results of the HPC beams. The analysis includes the relationship between the value of cracking and ultimate loads, deflection, concrete strain and steel strain for tested beams. The characteristic of tested beams at cracking, cracking shear load, 0.6 ultimate load and ultimate load are given in table (4) to (7) the values of the experimental values of beams are in fig (19) to (24).

Journal of Engineering Sciences, Assiut University, Faculty of Engineering, Vol. 41, No. 6, November, 2013,E-mail address: jes@aun.edu.eg 
Abeer Mohamed Nageeb Mohamed et al., Effect of fibers type on flexural behavior of high performance concrete beams under repeated load, pp. $2103-2125$

Table 4.

The characteristic of tested beams at cracking loads.

\begin{tabular}{|c|c|c|c|c|c|c|}
\hline Group & series & Type of fiber & $\begin{array}{c}\text { Pcr } \\
\text { (ton) }\end{array}$ & $\begin{array}{l}\text { Deflection } \\
\delta \mathrm{cr}(\mathrm{mm}) \\
\end{array}$ & $\begin{array}{c}\text { Concrete } \\
\text { Strain } / 10^{-5} \\
\mathbf{c c r} \\
\end{array}$ & $\begin{array}{c}\text { Steel Strain } \\
/ 10^{-5} \\
\\
\text { ecr } \\
\end{array}$ \\
\hline \multirow{4}{*}{ static } & Bs0 & without & 4 & 1.87 & 30 & 19 \\
\hline & Bsh & harex & 5 & 1.57 & 34 & 20.5 \\
\hline & Bsp & polypropylene & 4.5 & 1.54 & 33 & 22.5 \\
\hline & Bsg & glass & 4 & 1.73 & 32 & 20 \\
\hline \multirow{4}{*}{ repeated } & $\mathrm{Br} 0$ & without & 4 & 1.87 & 30 & 19 \\
\hline & Brh & harex & 5 & 1.57 & 34 & 20.5 \\
\hline & Brp & polypropylene & 4.5 & 1.54 & 33 & 22.5 \\
\hline & $\mathrm{Brg}$ & glass & 4 & 1.73 & 32 & 20 \\
\hline
\end{tabular}

Table 5.

The characteristic of tested beams at cracking shear loads.

\begin{tabular}{|c|c|c|c|c|c|c|}
\hline Group & series & Type of fiber & Qcr (ton) & $\begin{array}{l}\text { Deflection } \\
\text { ocr }(\mathrm{mm})\end{array}$ & $\begin{array}{c}\text { Concrete } \\
\text { Strain } / 10^{-5} \\
\text { ccr }\end{array}$ & $\begin{array}{c}\text { Steel } \\
\text { Strain } \\
/ 10^{-5} \\
\\
\mathrm{ccr}\end{array}$ \\
\hline \multirow{4}{*}{ static } & $\mathrm{Bs} 0$ & without & 5 & 2.58 & 46.5 & 27 \\
\hline & Bsh & harex & 8.5 & 3.5 & 59.5 & 37.5 \\
\hline & Bsp & polypropylene & 7 & 3 & 52.5 & 35 \\
\hline & Bsg & glass & 5 & 2.29 & 37.5 & 26.5 \\
\hline \multirow{4}{*}{ repeated } & $\mathrm{Br} 0$ & without & 5 & 2.58 & 46.5 & 27 \\
\hline & Brh & harex & 8.5 & 3.5 & 59.5 & 37.5 \\
\hline & Brp & polypropylene & 7 & 3 & 52.5 & 35 \\
\hline & $\mathrm{Brg}$ & glass & 5 & 2.29 & 37.5 & 26.5 \\
\hline
\end{tabular}

Journal of Engineering Sciences, Assiut University, Faculty of Engineering, Vol. 41, No. 6, November, 2013,E-mail address: jes@aun.edu.eg 
2115

Abeer Mohamed Nageeb Mohamed et al., Effect of fibers type on flexural behavior of high performance concrete beams under repeated load, pp. $2103-2125$

Table 6.

The characteristic of tested beams at 0.6 ultimate static loads.

\begin{tabular}{|c|c|c|c|c|c|c|}
\hline Group & series & Type of fiber & $\operatorname{Pr}($ ton) & $\begin{array}{l}\text { Deflection } \\
\delta \text { r (mm) }\end{array}$ & $\begin{array}{c}\text { Concrete } \\
\text { Strain } / 10^{-5} \\
\text { cr }\end{array}$ & $\begin{array}{c}\text { Steel } \\
\text { Strain } \\
/ 10^{-5} \\
\text { cr }\end{array}$ \\
\hline \multirow{4}{*}{ static } & $\mathrm{Bs} 0$ & without & 9.12 & 6.28 & 81.2 & 57.28 \\
\hline & Bsh & harex & 10.5 & 4.57 & 77.25 & 48.75 \\
\hline & Bsp & polypropylene & 9.84 & 5.14 & 78.5 & 49.2 \\
\hline & Bsg & glass & 8.7 & 5.28 & 72 & 48.5 \\
\hline \multirow{4}{*}{ repeated } & $\mathrm{Br} 0$ & without & 9.12 & 6.28 & 81.2 & 57.28 \\
\hline & Brh & harex & 10.5 & 4.57 & 77.25 & 48.75 \\
\hline & Brp & polypropylene & 9.84 & 5.14 & 78.5 & 49.2 \\
\hline & Brg & glass & 8.7 & 5.28 & 72 & 48.5 \\
\hline
\end{tabular}

Table 7.

The characteristic of tested beams at ultimate loads.

\begin{tabular}{|c|c|c|c|c|c|c|}
\hline Group & series & Type of fiber & Pu (ton) & $\begin{array}{l}\text { Deflection } \\
\delta u(m m)\end{array}$ & $\begin{array}{c}\text { Concrete } \\
\text { Strain } / 10^{-5} \\
\text { cu }\end{array}$ & $\begin{array}{c}\text { Steel } \\
\text { Strain } \\
/ \mathbf{1 0}^{-5} \\
\mathbf{c u}\end{array}$ \\
\hline \multirow{4}{*}{ static } & $\mathrm{Bs} 0$ & without & 15.2 & 14.5 & 175 & 120 \\
\hline & Bsh & harex & 17.5 & 12.7 & 220 & 160 \\
\hline & Bsp & polypropylene & 16.4 & 13.1 & 190 & 144 \\
\hline & Bsg & glass & 14.5 & 13.4 & 160 & 115 \\
\hline \multirow{4}{*}{ repeated } & Br0 & without & 15 & 16.2 & 233 & 148 \\
\hline & Brh & harex & 17.7 & 13.09 & 245 & 160 \\
\hline & Brp & polypropylene & 16.5 & 14.95 & 240 & 155 \\
\hline & $\mathrm{Brg}$ & glass & 8.7 & 15.89 & 210 & 135 \\
\hline
\end{tabular}

Journal of Engineering Sciences, Assiut University, Faculty of Engineering, Vol. 41, No. 6, November, 2013, E-mail address: jes@aun.edu.eg 
Abeer Mohamed Nageeb Mohamed et al., Effect of fibers type on flexural behavior of high performance concrete beams under repeated load, pp. $2103-2125$

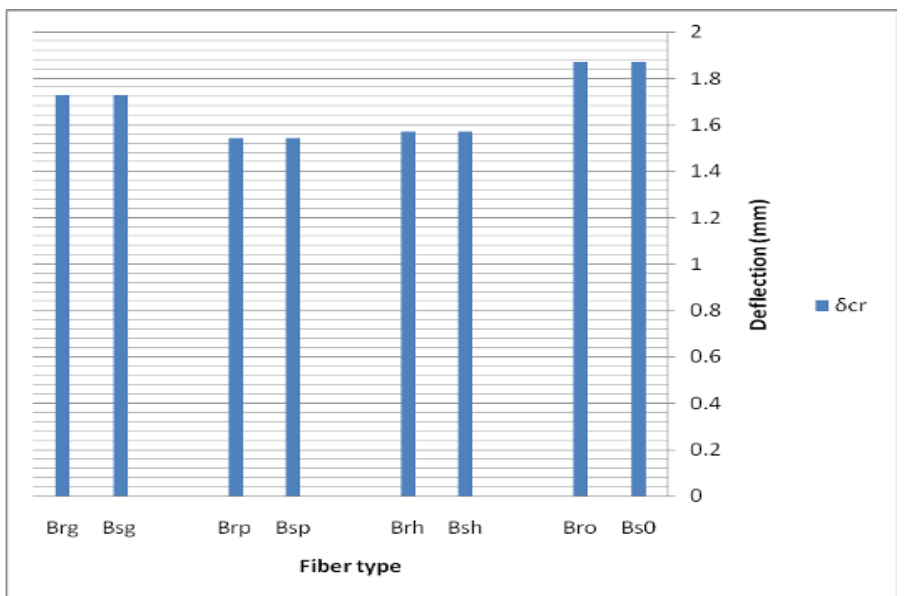

Fig. 19. The values of deflection of beams tested under static and repeated load at cracking load

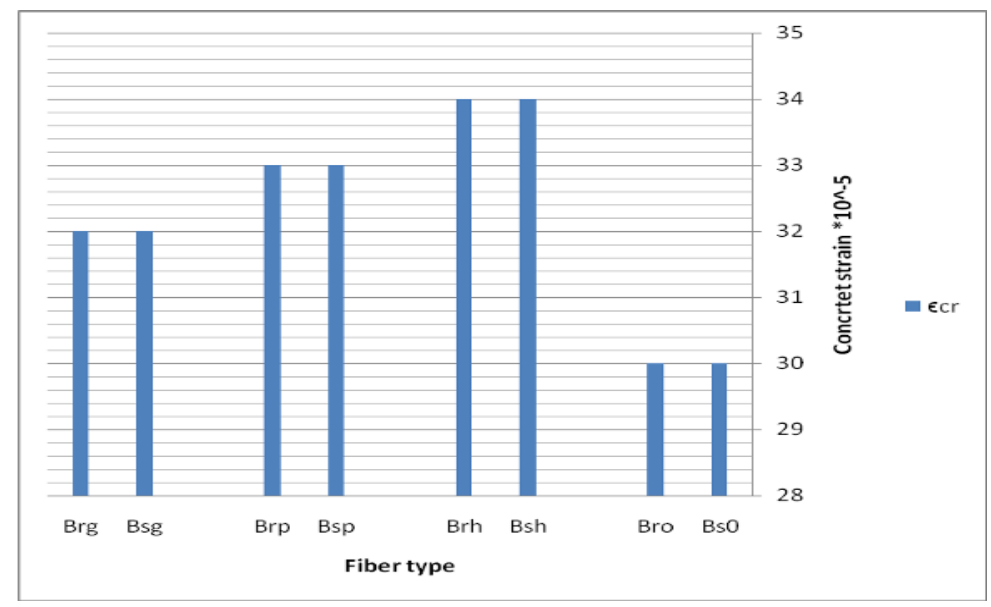

Fig. 20. The values of concrete strain of beams tested under static and repeated load at cracking load

Journal of Engineering Sciences, Assiut University, Faculty of Engineering, Vol. 41, No. 6, November, 2013, E-mail address: jes@aun.edu.eg 
Abeer Mohamed Nageeb Mohamed et al., Effect of fibers type on flexural behavior of high performance concrete beams under repeated load, pp. $2103-2125$

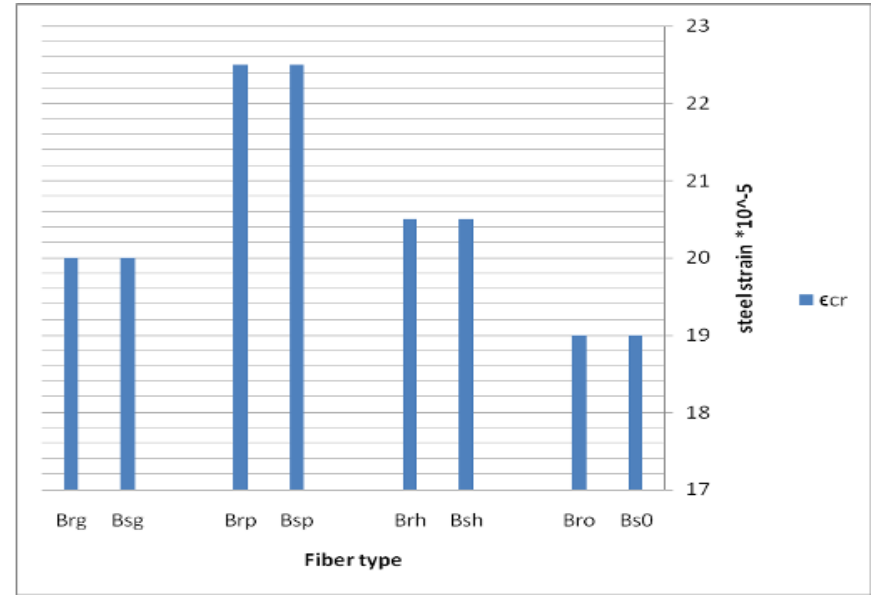

Fig. 21. The values of steel strain of beams tested under static and repeated load at cracking load

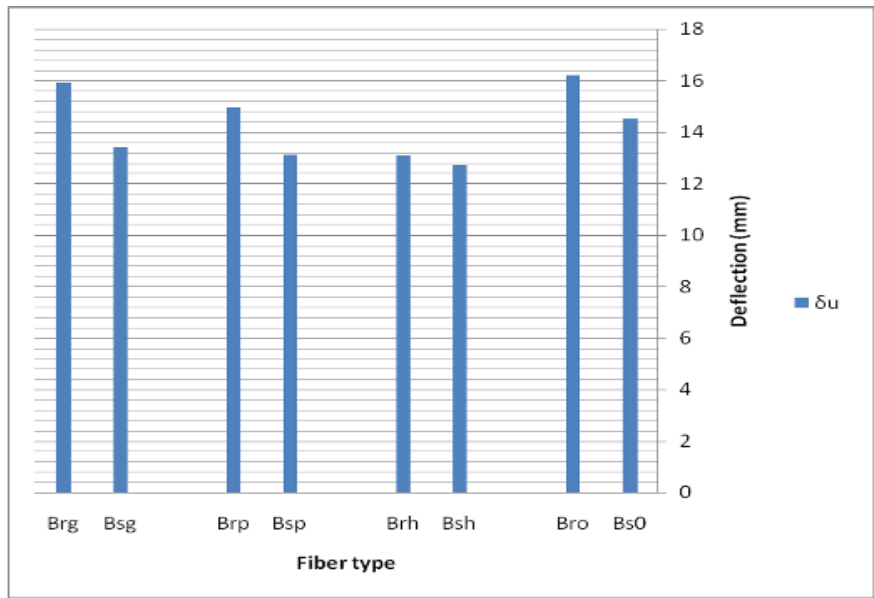

Fig. 22. The values of deflection at ultimate load of beams tested under static and repeated load

Journal of Engineering Sciences, Assiut University, Faculty of Engineering, Vol. 41, No. 6, November, 2013, E-mail address: jes@aun.edu.eg 
Abeer Mohamed Nageeb Mohamed et al., Effect of fibers type on flexural behavior of high performance concrete beams under repeated load, pp. $2103-2125$

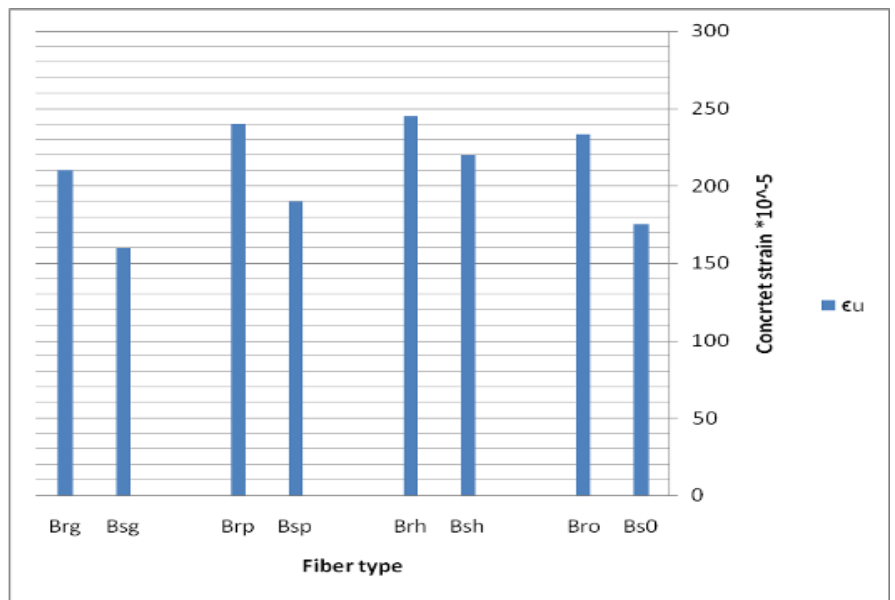

Fig. 23. The values of concrete strain at ultimate load of beams tested under static and repeated load

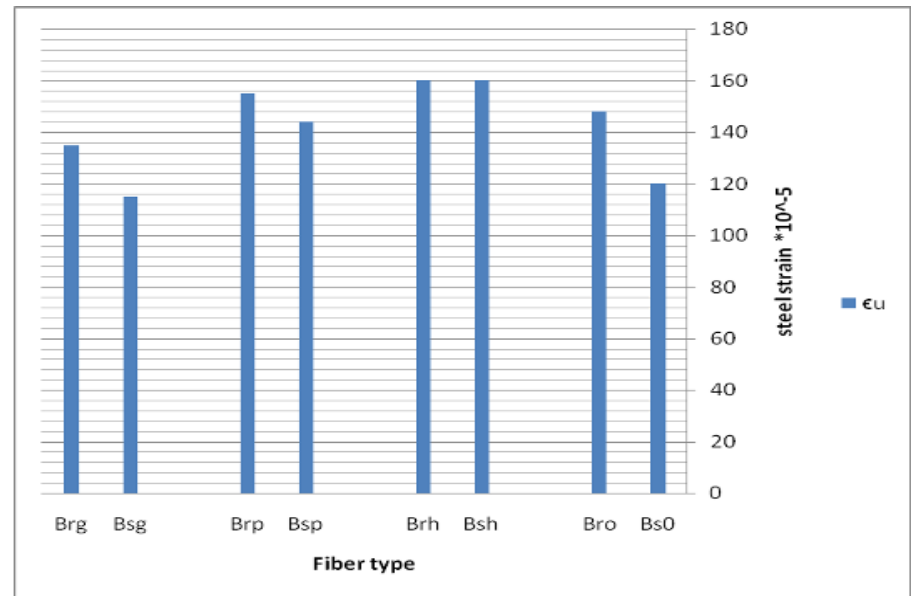

Fig. 24. The values of steel strain at ultimate load of beams tested under static and repeated load

\section{Effect of number of cycles $(N)$ for beams tested under repeated loading.}

The values of deflection, concrete and steel strains are measured at mid span of the beam with fibers and without fibers. The values of the measured deflection, concrete and steel strains due to $(\mathrm{N})$ cycles shown in Table (8) to (10). The comparison between beam without fibers $(\mathrm{Br} 0)$ for repeated loading with beams have fibrous content Harex, polypropylene and glass fibers are included in Figs. (25) to (27).

Journal of Engineering Sciences, Assiut University, Faculty of Engineering, Vol. 41, No. 6, November, 2013, E-mail address: jes@aun.edu.eg 
2119

Abeer Mohamed Nageeb Mohamed et al., Effect of fibers type on flexural behavior of high performance concrete beams under repeated load, pp. $2103-2125$

Table 8.

Values of experimental deflection at $(\mathrm{N})$ cycles for beams tested under repeated load.

\begin{tabular}{|c|c|c|c|c|c|c|c|}
\hline Group & series & $\begin{array}{c}\text { Def. at } \\
(\mathrm{N})=0\end{array}$ & $\begin{array}{c}\text { Def. at } \\
(\mathrm{N})=0.25 \\
\text { million }\end{array}$ & $\begin{array}{l}\text { Def. at } \\
(\mathrm{N})=0.5 \\
\text { million }\end{array}$ & $\begin{array}{c}\text { Def. at } \\
(\mathrm{N})=0.75 \\
\text { million }\end{array}$ & $\begin{array}{c}\text { Def. at } \\
(\mathrm{N})=1 \\
\text { million }\end{array}$ & $\delta_{\mathrm{u}}$ \\
\hline \multirow{4}{*}{$\begin{array}{c}\text { repeated } \\
\text { loads }\end{array}$} & Br0 & 6.28 & 7.1 & 7.9 & 9.1 & 9.9 & 16.2 \\
\hline & Brh & 4.57 & 5.17 & 5.77 & 6.14 & 6.74 & 13.09 \\
\hline & Brp & 5.14 & 5.79 & 6.44 & 7.14 & 7.79 & 14.45 \\
\hline & $\mathrm{Brg}$ & 5.28 & 15.89 & - & - & - & 15.89 \\
\hline
\end{tabular}

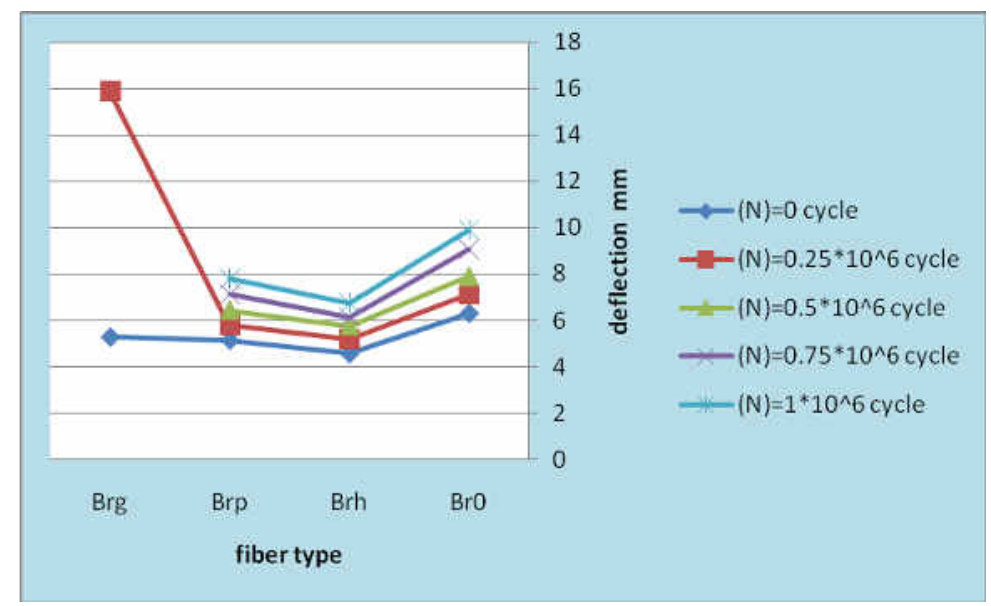

Fig. 25. The values of the deflection due to(N) cycles of tested beams under repeated load.

Journal of Engineering Sciences, Assiut University, Faculty of Engineering, Vol. 41, No. 6, November, 2013,E-mail address: jes@aun.edu.eg 
Abeer Mohamed Nageeb Mohamed et al., Effect of fibers type on flexural behavior of high performance concrete beams under repeated load, pp. $2103-2125$

Table 9.

Values of experimental concrete strain at $(\mathrm{N})$ cycles for beams tested under repeated load.

\begin{tabular}{|c|c|c|c|c|c|c|c|}
\hline Group & series & $\begin{array}{c}\text { Concrete } \\
\text { strain at } \\
(\mathbf{N})=\mathbf{0} \\
\times \mathbf{1 0}^{\wedge-5}\end{array}$ & $\begin{array}{c}\text { Concrete } \\
\text { strain at } \\
(\mathbf{N})=0.25 \\
\text { million } \\
\times 10^{\wedge-5}\end{array}$ & $\begin{array}{c}\text { Concrete } \\
\text { strain at } \\
(\mathbf{N})=0.5 \\
\text { million } \\
\times 10^{\wedge-5}\end{array}$ & $\begin{array}{c}\text { Concrete } \\
\text { strain at } \\
(\mathbf{N})=0.75 \\
\text { million } \\
\times 10^{\wedge-5}\end{array}$ & $\begin{array}{c}\text { Concrete } \\
\text { strain at } \\
(\mathbf{N})=1 \\
\text { million } \\
\times 10^{\wedge-5}\end{array}$ & $\epsilon_{c u} \times 10^{\wedge-5}$ \\
\hline \multirow{4}{*}{$\begin{array}{l}\text { repeated } \\
\text { loads }\end{array}$} & Br0 & 86 & 100 & 120 & 140 & 160 & 233 \\
\hline & Brh & 77.25 & 91 & 109 & 108 & 126 & 245 \\
\hline & Brp & 78.5 & 100 & 120 & 125 & 145 & 240 \\
\hline & $\mathrm{Brg}$ & 72 & 210 & - & - & - & 210 \\
\hline
\end{tabular}

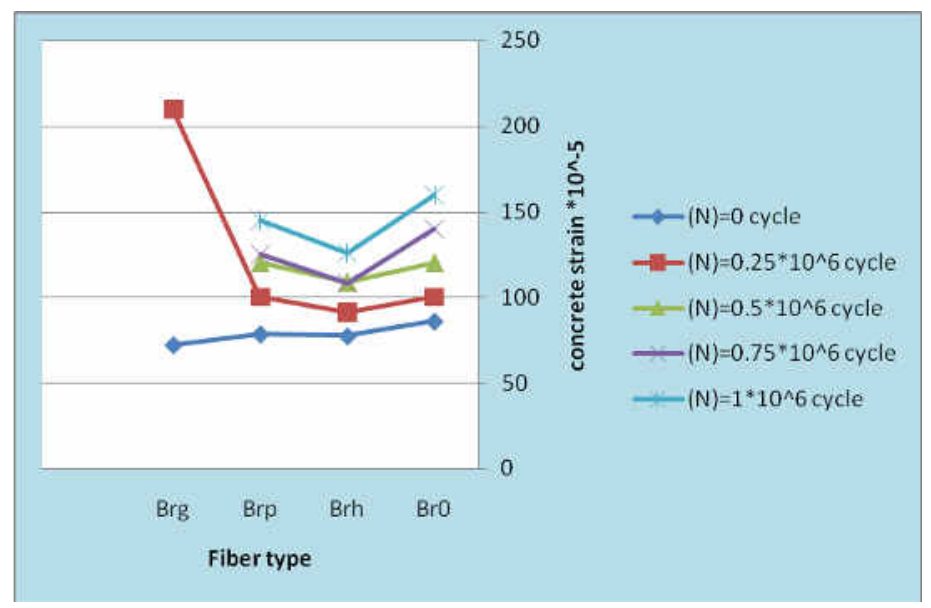

Fig. 26. The values of the concrete strain due to(N) cycles of tested beams under repeated load.

Journal of Engineering Sciences, Assiut University, Faculty of Engineering, Vol. 41, No. 6, November, 2013, E-mail address: jes@aun.edu.eg 
2121

Abeer Mohamed Nageeb Mohamed et al., Effect of fibers type on flexural behavior of high performance concrete beams under repeated load, pp. $2103-2125$

Table 10.

Values of experimental steel strain at $(\mathrm{N})$ cycles for beams tested under repeated load.

\begin{tabular}{|c|c|c|c|c|c|c|c|}
\hline Group & series & $\begin{array}{c}\text { steel } \\
\text { strain at } \\
(\mathbf{N})=0 \\
\times \mathbf{1 0}^{\wedge-5}\end{array}$ & $\begin{array}{c}\text { steel } \\
\text { strain at } \\
(\mathbf{N})=0.25 \\
\text { million } \\
\times 10^{\wedge-5}\end{array}$ & $\begin{array}{c}\text { steel } \\
\text { strain at } \\
(\mathbf{N})=0.5 \\
\text { million } \\
\times 10^{\wedge}-5\end{array}$ & $\begin{array}{c}\text { steel } \\
\text { strain at } \\
(\mathbf{N})=0.75 \\
\text { million } \\
\times 10^{\wedge-5}\end{array}$ & $\begin{array}{c}\text { steel } \\
\text { strain at } \\
(\mathbf{N})=1 \\
\text { million } \\
\times 10^{\wedge-5}\end{array}$ & $\epsilon_{u} \times 10^{\wedge-5}$ \\
\hline \multirow{4}{*}{$\begin{array}{c}\text { repeated } \\
\text { loads }\end{array}$} & $\mathrm{Br} 0$ & 60.4 & 70 & 84 & 84 & 98 & 148 \\
\hline & Brh & 48.75 & 56 & 67.5 & 65.5 & 82.5 & 160 \\
\hline & Brp & 49.2 & 62.5 & 75 & 82.5 & 95 & 155 \\
\hline & $\mathrm{Brg}$ & 48.5 & 135 & - & - & - & 135 \\
\hline
\end{tabular}

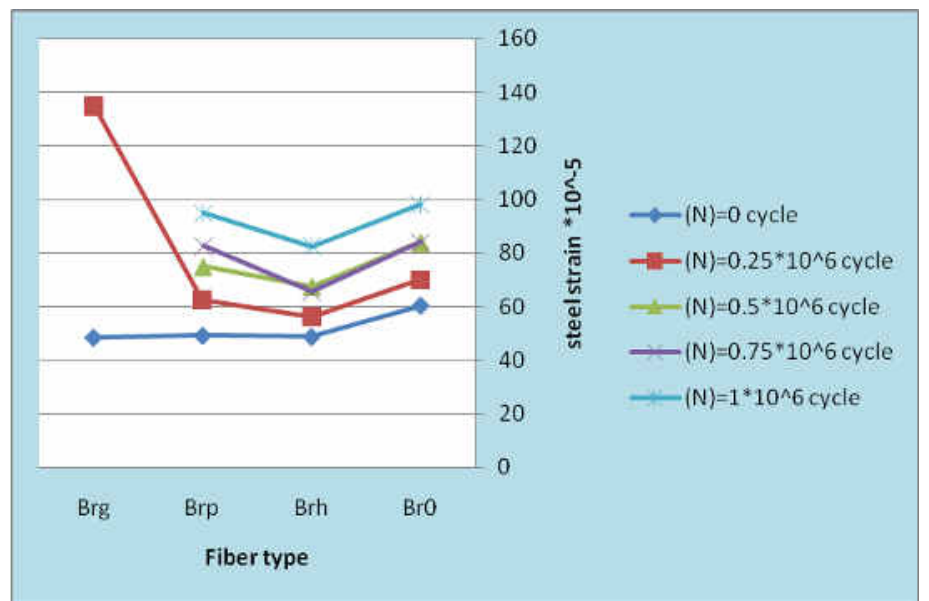

Fig. 27. The values of the steel strain due to(N) cycles of tested beams under repeated load.

\section{Conclusions}

This work presents an experimental study on the behavior of high performance reinforced concrete beams (H.P.C) with and without fibers subjected to static and repeated loading. From the test result and their analysis, the following conclusions are obtained:

Journal of Engineering Sciences, Assiut University, Faculty of Engineering, Vol. 41, No. 6, November, 2013,E-mail address: jes@aun.edu.eg 
Abeer Mohamed Nageeb Mohamed et al., Effect of fibers type on flexural behavior of high performance concrete beams under repeated load, pp. $2103-2125$

\section{1- For static load test}

a) Harex fibers beam has an increase in the ultimate load by $15.1 \%$, decrease in deflection by $12.4 \%$ and increase in ultimate concrete and steel strain by $25.7 \%$, $33.3 \%$ respectively.

b) Polypropylene fibers beam has an increase in the ultimate load by $7.9 \%$, decrease in deflection by $9.7 \%$ and increase in ultimate concrete and steel strain by $8.6 \%$, $20 \%$ respectively.

c) Glass fibers beam has decrease in the ultimate load by $4.6 \%$, decrease in deflection by $7.6 \%$ and decrease in ultimate concrete and steel strain by $8.6 \%, 4.2 \%$ respectively.

\section{2- For repeated load test}

a) Harex fibers beam has an increase in the ultimate load by $18 \%$, decrease in deflection by $19.2 \%$ and increase in ultimate concrete and steel strain by $5.2 \%, 8.1 \%$ respectively.

b) Polypropylene fibers beam has an increase in the ultimate load by $10 \%$, decrease in deflection by $7.7 \%$ and increase in ultimate concrete and steel strain by $3 \%$, $4.7 \%$ respectively.

c) Glass fibers beam has decrease in the ultimate load by $42 \%$, decrease in deflection by $1.9 \%$ and decrease in ultimate concrete and steel strain by $9.9 \%, 8.8 \%$ respectively.

d) Harex steel fiber improved the shear and flexural capacity for beams under static and repeated loading, The mode of failure changed from shear to flexural failure.

e) Both fiber reinforced concrete beams with Harex and polypropylene has mode of failure flexural and shear flexural failure because of the fiber addition enhanced shear strength for fiber concrete beams.

f) The addition of Harex and polypropylene fibers to reinforced concrete beams increases the fatigue life and decreases the crack number and its width under fatigue loading.

g) Flexure strength of beams with harex steel fiber is substantially greater than beams without fibers in tension or compression because ductile behavior of the FRC on the tension side of a beam alters the normally elastic distribution of stress and strain over the member depth.

h) Additional of the fibers in the concrete mixture confine the cracking behavior of the HPC beam.

i) Fiber reinforced concrete has substantial enhancement of the load carrying capacity of the FRC beams with harex and polypropylene.

j) The first-crack tensile strength and the ultimate tensile strength of the concrete increased by harex and polypropylene fibers.

$\mathrm{k}$ ) It is not recommended to use reinforced concrete beams with glass fibers under the effect of repeated loading resulting unability to resist this kind of loading.

Journal of Engineering Sciences, Assiut University, Faculty of Engineering, Vol. 41, No. 6, November, 2013, E-mail address: jes@aun.edu.eg 
Abeer Mohamed Nageeb Mohamed et al., Effect of fibers type on flexural behavior of high performance concrete beams under repeated load, pp. $2103-2125$

\section{References}

[1] K. komlos, B. Babal, and T. Nurnbergerova. 1995. Hybrid fiber- reinforced concrete under repeated loading. Nuclear Engineering and Design. 156: 195-200.

[2] H. Mihashi, A. Kawamata, Y. Kaneko and K. Kirikosha. 2000. Influence of fracture toughness of matrix on the ductility of fiber reinforced cementitious composites. Fiber reinforced concrete (FRC) BEFIB, Proceedings of the $5^{\text {th }}$ international RILEM symposium. pp. 597-606.

[3] J. Zhang and H. Stang. 1998. Application of stress crack width relationship in predicting the flexural behaviour of fiber reinforced concrete. Cement and Concrete Research. 28(3): 439452.

[4] Johnston C.D. 1974. Steel fiber reinforced mortar and concrete-A review of mechanical properties. Fiber reinforced concrete, SP-44, American Concrete, Detroit. pp. 127-142

[5] Naaman A. E. 1985. Fiber reinforcement for concrete. Concrete international design and construction. 7(3): 21-25.

[6] Romualdi, J. P. and Batson G. B. 1963. Mechanics of crack arrest in concrete. J. Eng. Mech. Div., ASCE. Vol. 89, No. EM3, June. pp. 147-168.

[7] John E. Bolander 2004. Numerical Modelling of Fiber Reinforced Cement Composites: Linking Material Scales. University of California, Davis, USA.

[8] Meda, A., Minelli, F., Plizzari, G. A., and Riva, P., (2005). Shear behaviour of steel fibre reinforced concrete beams. Materials and Structures, 38, April 2005, pp. 343-351.

[9] Minelli, F., (2005). Plain and fiber reinforced concrete beams under shear loading: Structural behaviour and design aspects. Ph.D Dissertation, University of Brescia: Department of Civil Engineering, $429 \mathrm{p}$.

[10] Noghabai, K. (2000). Beams of fibrous concrete in shear and bending: Experiment and model. Journal of Structural Engineering, 126(2), February 2000, pp. 243-251.

[11] Richardson, A.E., and Landless, S., (2009). Synthetic fibres and steel fibres in concrete with regard to bond strength and toughness. Northumbria Working Paper Series: Interdisciplinary Studies in the Built and Virtual Environment, December 2009, pp. 128140.

[12] Wang, Y., Backer, S., and Li, V. C., (1987). An experimental study of synthetic fibre reinforced cementitious composites. Journal of Materials Science, 22(12), December 1987, pp. $4281-4291$.

[13] Lee, S. C., Cho, J. Y., and Vecchio, F. J., (2013). Simplified diverse embedment model for SFRC elements in tension. American Concrete Institute Materials Journal, 110(3).

Journal of Engineering Sciences, Assiut University, Faculty of Engineering, Vol. 41, No. 6, November, 2013,E-mail address: jes@aun.edu.eg 
Abeer Mohamed Nageeb Mohamed et al., Effect of fibers type on flexural behavior of high performance concrete beams under repeated load, pp. 2103 - 2125

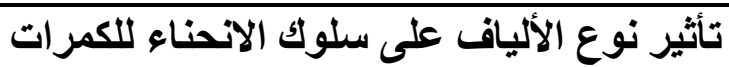 \\ الخرسانية عالية المقاومة تحت تأبثير الأحمال المتكررة}

الملخص العربي

تعد الخرسانة واحدة من اكثر المواد قصافة التي لها مقاومة ضعيفة للشد. تم تطوير الخرسانة ذات

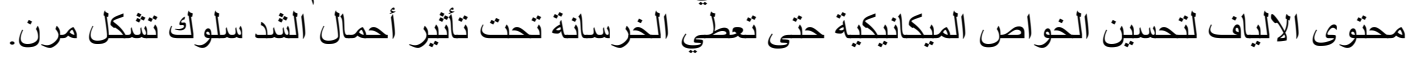

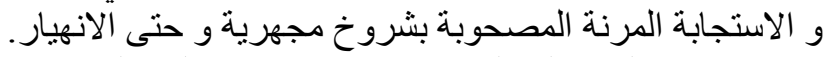

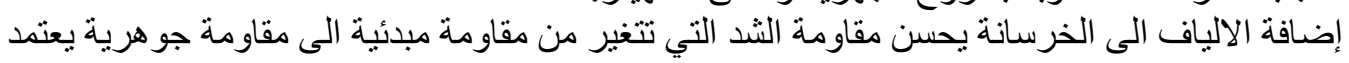

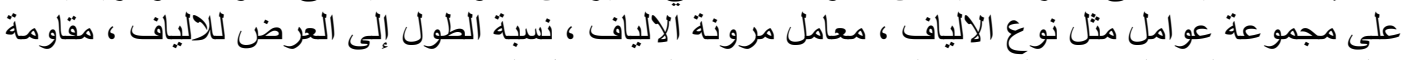

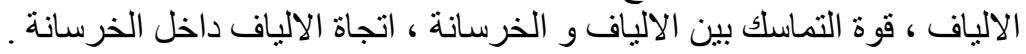

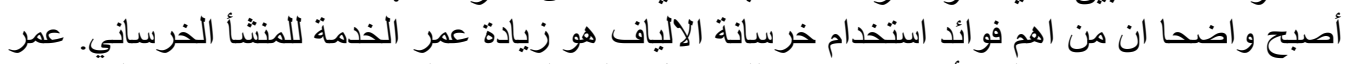

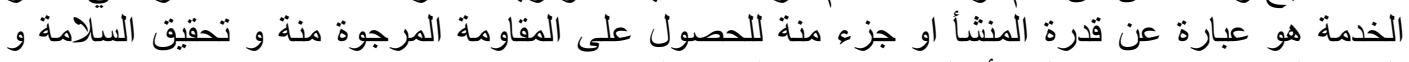

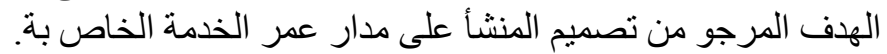

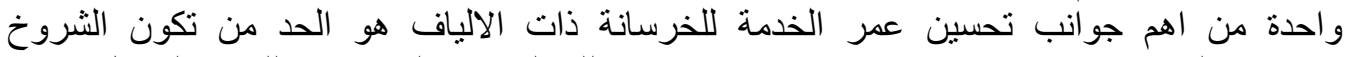

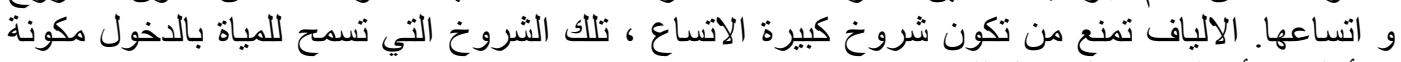
صدأ الحديد أو التدهور الياف المحتمل للخرسانة. و بدر اسة سلوك الخرسانة تحت الأحمال الاستاتيكيةو الأحمال المتكررة وجد أن: 1. الكمرات ذات محتوى الياف الهاركس لها مقاومة اعلي في منطقة العزوم و القص تحت تأثثر الأحمال

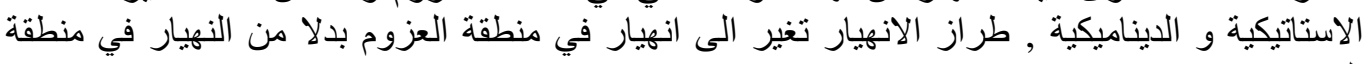
2. الكمر ات ذات محتوى ألياف البولي بروبيلين لها مقاومة اعلي في حالة العزم و القص تحت تأثير الأحمال

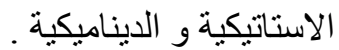
3. إضافة كلا من ألياف الهاركس و البئية البولي بروبيلين حسن من تحمل الكمرات للأحمال المتكررة و قلل من عدد الشروخ و أتساعها.

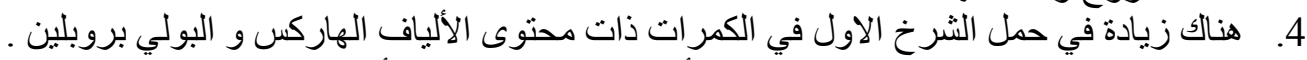

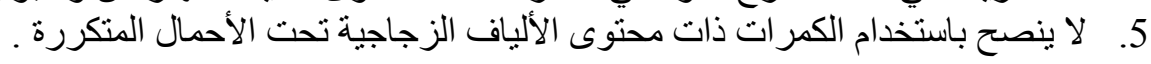

Journal of Engineering Sciences, Assiut University, Faculty of Engineering, Vol. 41, No. 6, November, 2013, E-mail address: jes@aun.edu.eg 